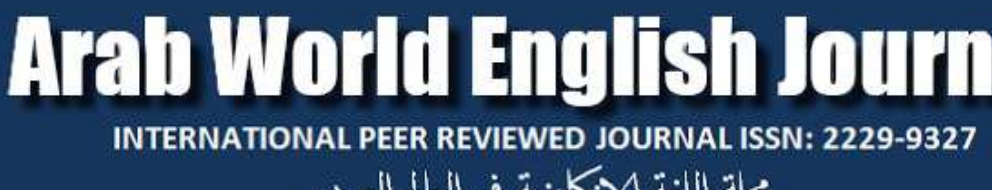 \\ بجاة اللفة الوكليزية في العالم العربي
}

Arab World English Journal (AWEJ) Volume 11. Number1 March 2020

DOI: https://dx.doi.org/10.24093/awej/vol11no1.29

Pp.432- 443

\section{The Influence of Implementing Reciprocal Teaching in L2 Classes on Female Students' Perception of their Reading Skills and Motivation to Read}

\author{
Maysa Mohammad Sadiq Qutob \\ English Language Institute, King Abdulaziz University, Jeddah, KSA \\ Albayan Model School for Girls, Jeddah, KSA
}

\begin{abstract}
This study aimed to investigate the effectiveness of reciprocal teaching (RT) in improving high school female students' attitudes toward reading in a second language as the results might shed light on effective teaching practices in the L2 classrooms. To this end, a self-report questionnaire was developed and validated by the researcher. A quasi-experimental design was used, whereby the study sample was divided into two groups, experimental and control. The experimental group was taught reading in English classes by means of RT strategies, whereas the matched control group was taught reading by means of traditional instructive techniques. Both groups completed the self-report questionnaire on reading skills and motivation during term time, ensuring that the participants in the experimental group completed the questionnaire within ten weeks of the intervention. The findings show significant correlations between RT strategies and both reading comprehension and motivation to read, and are also effective in improving students' perception of their reading skills and motivation to read. Accordingly, the study recommends other researchers to investigate the effect of RT on students' performance and considering implementing RT with the use of technology in English as foreign language (EFL) classrooms.
\end{abstract}

Keywords: clarifying, EFL, motivation, reading comprehension, predicting, questioning, reciprocal teaching, students' perception, summarizing, teaching methodology, teaching strategies

Cite as: Qutob, M. M. S. (2020). The Influence of Implementing Reciprocal Teaching in L2 Classes on Female Students' Perception of their Reading Skills and Motivation to Read. Arab World English Journal, 11 (1) 432- 443.

DOI: https://dx.doi.org/10.24093/awej/vol11no1.29 


\section{Introduction}

It is essential that $21^{\text {st }}$-century students are able to communicate fluently with interlocutors from different cultural and ethnic backgrounds. Given that English is the world's principal lingua franca, and used by most scientific publications and media outlets, many non-native English-speaking education systems have introduced English instruction to school-age learners. Within tuition for this age range, reading comprehension is considered the core skill which will enable every student to build their knowledge and achieve better outcomes. The Arabic language is different from European languages in many ways, including lexicon, sentence structure and direction of writing. For all these reasons, Arabic speakers face particular challenges in learning English.

Reading is one of the most difficult language skills to acquire, as it requires students to visually perceive words, process their phonological codes and understand the semantic meaning of a word itself as well as its meaning within the sentence. This complex procedure demands a high level of both skill and motivation from English as a foreign language (EFL) learners. The current study, therefore, aims to shed light on how teaching can improve non-native English learners' perceptions of their comprehension skills and motivation in relation to reading English texts. In particular, it will examine the effectiveness of reciprocal teaching (RT), an educational strategy which has seen increasing use, in improving such perceptions.

\section{Literature Review}

Over the past few decades, studies have investigated a range of strategies to improve reading comprehension. These include questioning (Rosenshine, Meister \& Chapman, 1996), clarifying (Graesser \& Lehman, 2011; Ishiwa, Sanjose \& Otero, 2013) and summarizing (Bean \& Steenwyk, 1984; Doctorow, Wittrock \& Marks, 1978; Head, Readence \& Buss, 1989; Wang, Sabatini, O'Reilly and Feng, 2017). McCrudden, Magliano and Schraw (2010) found that readers must be given appropriate instructions to improve their deep processing of texts saying, "relevance instructions affect reader goals, processing, and comprehension" (p. 229) (see also Ramsay and colleagues, 2010). Other researchers concur, agreeing that when teachers implement an appropriate strategy, students become engaged and motivated in the reading class (Ilter, 2009; Soufi, Saad and Nicolas, 2015).

Other scholars have extended this line of research to strategies and factors which improve reading comprehension within EFL, given the importance, as noted above, of acquiring this core skill (Ahmadi, Ismail \& Abdullah, 2013; Krashen, 1989; Ninsuwan, 2015). Reading comprehension can be regarded as the process of getting meaningful information from a written language (Zablocki, Horn \& Cuenca-Carlino, 2017) and, as Ahmadi, Ismail and Abudlla (2013) point out, has a positive impact on language acquisition and communication skills. Krashen (1989) similarly states that reading comprehension helps vocabulary acquisition and spelling.

Since successful EFL teaching depends on both teachers and learners being and remaining strongly motivated, it is crucial to consider the impact of teaching strategies on students' motivation. Gulbinskiene and Dubovičienè (2015) state that motivation is best performed in classrooms; therefore, it is imperative that EFL teachers make their classrooms enjoyable by applying motivating strategies that suit today's learners. Soufi, Saad and Nicolas (2015) discovered that using blogs in reading classes had a positive impact on EFL learners' motivation 
to read, as well as boosting critical thinking skills. Moreover, Ilter (2009) concludes that the use of technology significantly contributes to an increase in motivation as regards EFL learners' reading.

Reciprocal teaching was started by Palincsar and Brown (1984). It is a guided reading comprehension instruction technique, where the teacher models the required learning behaviours, after which students themselves become the teachers by forming small groups to discuss the texts and support each other's learning. Palincsar and Brown (1984) selected the following four engagement strategies to represent RT within small discussion groups in which students themselves take the lead:

1) Predicting what will come next in the text being read, which allows students to draw inferences;

2) Clarifying, which improves students' critical thinking;

3) Questioning, which helps students to comprehend ambiguous concepts in a text; and

4) Summarizing, which guides students to focus on comprehension.

Additionally, the four main components of RT have recently been applied to the tuition and practice of reading in EFL classes (Al-Harby, 2016; Ashegh, 2018; Pilten, 2016; Sheng-Shiang \& Hui-Chin, 2018). Ninsuwan (2015) suggests that RT skills are of particular use in aiding EFL learners to comprehend new words, as well as master different approaches to learning English.

Palincsar and Brown (1984) conducted two studies on different groups of the same age (seventh grade) at separate times, and revealed the beneficial effect of RT strategies on pupils' reading comprehension skills in different subjects. Many studies have since been carried out to examine the effectiveness of RT on the comprehension of participants of different age groups (Liu \& Bu, 2016; Pilten, 2016; Reichenberg \& Kent, 2014; Schünemann, Spörer, Völlinger \& Brunstein, 2017; Sheng-Shiang \& Hui-Chin, 2018). A quasi-experimental study carried out in Sweden by Reichenberg and Kent (2014) suggests that RT improves third-grade students' comprehension, while similar results with elementary students were found by Pilten (2016) in Turkey and Schünemann, Spörer, Völlinger and Brunstein (2017) in Germany. Moreover, Liu and $\mathrm{Bu}$ (2016) found that RTS improved language proficiency among first-year university students in Shanghai. Finally, RTS outside the regular education system was investigated by Ashegh (2018), who verified its effectiveness within a continuing education programme on the reading comprehension skills of intermediate adult EFL students. Ashegh (2018) stated, "reciprocal teaching could improve reading comprehension performance of EFL intermediate learners in Iran" (p. 28).

There has been some debate over whether all four of the elements within RT are of equal benefit. For example, the theoretical paper by Ahmadi and Gilakjani (2012) emphasizes the benefits to be gained by implementing all four RT strategies. On the other hand, Sheng-Shiang and Hui-Chin (2018) indicated, using reflective essays produced by undergraduate students in Taiwan after RT sessions, that the questioning and predicting strategies were the most useful for their comprehension of English texts. 
Other researchers have examined the achievements of RT on students with different proficiency levels and reading abilities (Huang \& Yang, 2015; Zablocki et al., 2017). Huang and Yang (2015) state that RT improved the skills of students with a low English level at the Technical University in Southern Taiwan. On the other hand, Zablocki et al. (2017) examined teenagers from various ethnic backgrounds and of low social status in an alternative school in the USA and found that they gained only slightly in proficiency. Soonthornmanee (2002) conducted an experiment on high and low reading achievers among Thai university EFL students, and found that the low achievers expressed a preference for RT, which helped develop their skills. An experiment conducted on disabled students also advocated the use of RT (Gomaa, 2015). Other studies have been conducted on the efficacy of RT on certain groups of Arabic-speaking students, for example, undergraduate students (Al-Harby, 2016).

Moreover, using RT has been seen to bring additional benefits to students. For example, first-grade students in Canada became significantly more engaged in the learning process by interacting and involving themselves in discussions with the teacher (Mandel, Osana \& Venkatesh, 2013). Tarchi and Pinto's (2016) study of third-grade students from different schools similarly concluded that RT fostered an interactive environment, while Schünemann and colleagues (2017) noticed an increase in team spirit, with peers supporting each other by offering constructive feedback.

\section{Research Question}

Given the body of research supporting the use of RT within EFL classrooms, the author of the current study investigated high school EFL students' opinions of this pedagogical approach as a means of improving their reading comprehension and increasing their motivation to read. A quantitative research method was used.

This research developed a self-report questionnaire to assess the effects of RT on the ability of $11^{\text {th }}$-grade female students' reading comprehension and motivation to read in a second language. The following research question was formulated: "Can applying RT in reading comprehension classes motivate second language (L2) learners and improve their reading comprehension?"

As several studies have assessed the effect of RT on non-Arabic EFL students' skills and attitudes (e.g., Mandel et al., 2013; Schünemann et al., 2017), the current study predicts similar findings among high school Arabic speakers.

\section{Significance of the study}

To date, no similar study has been conducted on high school students in Jeddah. Therefore, the current study adds to the field of research into EFL teaching by considering uncovered aspects in previous studies in RT with regard to age, methodology and context. The participants are middle-class females at a private school in Jeddah, Saudi Arabia.

\section{Methodology}

The present study implements a quantitative quasi-experimental design to investigate the effects of RT on students' reading strategies, reading comprehension and motivation to read. Additionally, it examines EFL students' perception of RT in relation to improving their reading comprehension and increasing their motivation to read. 


\section{Participants}

A total of 192 EFL female learners, aged 15-16, attending a private high school in Jeddah, Saudi Arabia, completed an electronic questionnaire. The participants are all Arabic speakers from a middle-class background, learning English as a foreign language. Although the average English proficiency of respondents is high B1, students' levels also included C1, B2 and A2, according to the Common European Framework (CEFR) scale of English Proficiency. Equal numbers were selected from six $11^{\text {th }}$-grade classes (15-20 participants from each class), across two terms. The students were taught by a teacher with a bachelor's degree in English and 18 years' high school teaching experience. The teacher applied RT and used the same materials and curriculum for all students.

\section{Instruments}

Questionnaire. A questionnaire of 13 items was developed for this study based on a 5point Likert scale, where $5=$ "strongly agree" and $1=$ "strongly disagree". The questionnaire has three dimensions - reading strategies, reading comprehension and motivation - and addressed the four RT strategies, namely predict, clarify, question and summarize. After the course instructor had reviewed the questionnaire, the items were translated into Arabic to ensure that the students understood them fully, and stored in electronic form on Google drive.

\section{Procedure}

All the students had been taught using RT in 10th grade EFL classes; thus, all were already aware of each strategy. However, as the study aims to compare reading strategies, comprehension and motivation across two groups of students, exposure to RT in the $11^{\text {th }}$-grade was controlled. In the control group, students were taught reading by traditional methods. In the eleventh week, this group was given an electronic questionnaire addressing students' perceptions of their reading abilities and motivation.

In the experimental group, the English teacher introduced the RT strategies prior to the reading course. RT strategies were used for 10 weeks (45 minutes per week), after which the questionnaire was administered. Moreover, the teacher clarified the meaning of each strategy and gave examples, in collaboration with the students. Each time the teacher gave a reading lesson, she reinforced the strategies and supplied the students with an RT group worksheet. In addition, she ensured that the students received worksheets of different formats to motivate them to work. In week 11, students completed the electronic form of the study questionnaire in the computer lab of the school. None of the students, across either group, were asked to provide personal data. Although there was no time limit for completing the form, most students took around five minutes.

\section{Reliability and validity}

The researchers confirmed reliability by calculating Cronbach's alpha using SPSS 21.0 software, which was also used to ensure validity by calculating internal consistency and examining the correlation between each individual item and the total score of the dimension and questionnaire. Furthermore, Pearson's correlation was used to verify the concurrent validity of the questionnaire and the study's hypotheses concerning the relationship between RT and reading comprehension and motivation. Additionally, independent sample $t$ tests were used to compare the reading abilities and motivation of the two groups. 


\section{Results}

Each item in the self-report questionnaire was assigned a score ranging from 1 to 5 , where $5=$ "strongly agree" and $1=$ "strongly disagree". As stated above, the questions were divided into three dimensions: (1) RT strategies (4 items); (2) reading comprehension (4 items); and (3) reading motivation (5 items). Therefore, each student was given a total score and three sub scores for the dimensions. As there are 13 items in the questionnaire, the lowest possible score was 13 and the highest 65 .

Reliability and validity. The questionnaire has a high level of reliability, with a Cronbach's Alpha of 0.85. Pearson's correlation was used to calculate the validity of the questionnaire, with items overall showing a significant correlation, with a total score of $p<.001$. Additionally, the researchers carried out a series of correlations between each item and the total score of the dimension within which they fell. Table 1 shows the correlation scores and significant level of each item with the total scores of both dimension and questionnaire. All items show a significant correlation with their dimensions, of $p<.001$. Hence, no item was eliminated from the analysis. The scores of the dimensions also positively correlated with the total score, at $r=0.87$, $r=0.87$ and $r=0.89$, for RT skills, reading comprehension and motivation to read respectively.

\section{Table 1.}

Correlations for items with total dimension and questionnaire scores

\begin{tabular}{|c|c|c|c|c|c|}
\hline \multirow[b]{2}{*}{ Dimensions } & \multirow[b]{2}{*}{ Items } & \multicolumn{2}{|c|}{$\begin{array}{c}\text { Correlations with the Dimension } \\
\text { Score }\end{array}$} & \multicolumn{2}{|c|}{$\begin{array}{c}\text { Correlations with the Total } \\
\text { Score }\end{array}$} \\
\hline & & Pearson's Correlation & Sig & Pearson's Correlation & Sig \\
\hline \multirow[t]{4}{*}{ RT strategies } & 1 & .641 & .001 & .357 & .02 \\
\hline & 2 & .547 & .001 & .343 & .001 \\
\hline & 3 & .624 & .001 & .38 & .001 \\
\hline & 4 & .565 & .001 & 349 & .001 \\
\hline \multirow[t]{4}{*}{ Reading comprehension } & 5 & .683 & .001 & .377 & .001 \\
\hline & 6 & .695 & .001 & .376 & .001 \\
\hline & 7 & .696 & .001 & .42 & .001 \\
\hline & 8 & .569 & .001 & .323 & .001 \\
\hline \multirow[t]{2}{*}{ Motivation to read } & 9 & .438 & .001 & .264 & .001 \\
\hline & 10 & .55 & .001 & .318 & .001 \\
\hline
\end{tabular}


The role of $\mathbf{R T}$ in reading abilities and motivation. An independent sample $t$ test was performed to compare the means of the questionnaire scores of the experimental and control groups. This revealed a significant difference between the total score of the experimental group $(M=44.49, S D=9.42)$ and the control group $(M=41.46, S D=19.51), \mathrm{t}(190)=2.11, p<.05$. A series of comparisons between the scores of the experimental and control groups in each dimension (reading strategies, reading comprehension and motivation to read) reveal significant results, with the experimental group scoring more highly than the control group in every case: $t(190)=1.71, t$ $(190)=1.76$, and $t(190)=1.98$, respectively, $p<.05$. Figure 1 gives means and standard errors of the total score of the questionnaire and sub scores of dimensions for each group.

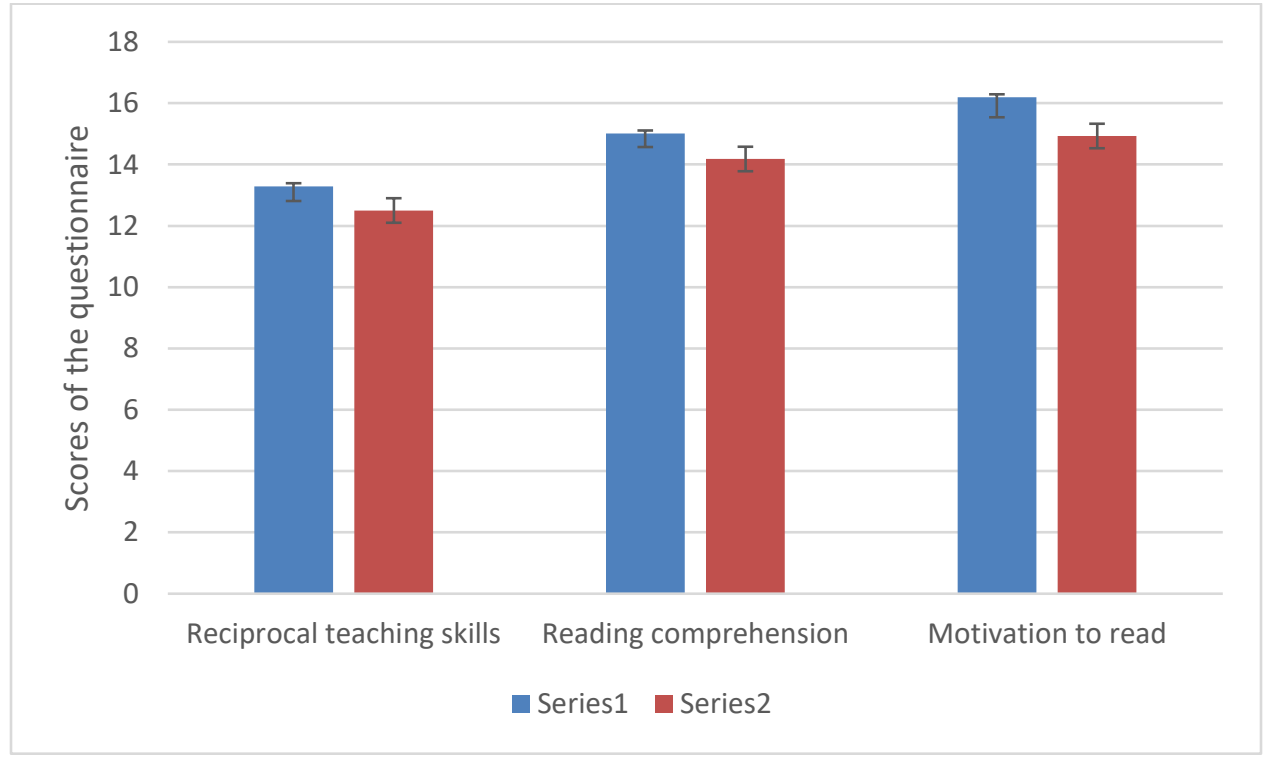

Figure 1. This figure illustrates the means and standard errors for each dimension of the self-report questionnaire for both the experimental and control group.

Correlations between reading abilities and motivation. Pearson's correlations show that students' perceptions of their RT skills are positively correlated with their perception of reading comprehension, $\mathrm{r}=.69, p<.001$, and with motivation to read, $\mathrm{r}=.63, p<.001$. Similarly, students' perception of their reading comprehension shows a significant positive correlation with motivation to read, $\mathrm{r}=.62, p<.001$. 


\section{Discussion}

In this study, the researcher investigates the impact of RT on high school students' perceptions of reading comprehension and motivation to read. Participants were recruited from one high school and were divided into two groups. One group was taught reading in English classes by means of RT strategies, while the other group was taught reading by means of the traditional instructive technique. Both groups completed a self-report questionnaire consisting of 13 items grouped in three dimensions: RT, reading comprehension and motivation.

The findings showed that RT had a significant effect on the students' attitude toward reading, shown by the significantly higher total scores of the questionnaire for the experimental than the control group. Additionally, the sub scores of the three dimensions of the questionnaire show similar significant differences, indicating that RT strategies influence variant components of students' perception of their reading attitudes. In addition, the results illustrate that there is a positive correlation between students' perception of RT skills and reading comprehension, and between RT skills and motivation.

Before implementing RT, teachers are assigned to workshops to practise the strategy (Palincsar \& Brown, 1984). Thereafter, the teacher introduces the strategy to the students by defining the meaning of each part and giving examples to engage students in the new method before it is applied in practice. As in the case of the participants in this study, the teacher and her students are familiarized with the new strategy prior to its use. Furthermore, the teacher reinforces the components of the strategy with students at the beginning of the course which, in turn, leads to smooth implementation.

Applying RT as a teaching strategy in EFL classrooms is meant to improve students' reading comprehension (Palincsar \& Brown, 1984). The current study supports the use of RT strategies in the EFL classroom to enhance reading as a tool to develop vocabulary (Mandel et al., 2013). It is clear from the results that most students agree that they are able to clarify words within context and find answers to comprehension questions.

The students engage well in group discussions due to the cooperative learning environment which fosters a motivation to establish communication with peers regarding the text (Tarchi \& Pinto, 2016). Consequently, students tend to read more about the topic provided in class, as this kind of strategy encourages autonomous learning (Liu \& Bu, 2016). These attainments provide scaffold learning and enhance a learner-centred environment, as students are responsible for their own learning process (Mandel et al., 2013) while the teacher remains the facilitator (Ahmadi \& Gilakjani, 2012).

The quantitative results can be generalized to the same age group of EFL learners with an Arabic background. Accordingly, EFL teachers may consider applying RT in their reading classes, as it produces effective outcomes with regard to comprehension skills and improves students' 
achievements when compared with the direct instruction strategy (Huang \& Yang, 2015). Additionally, Tarchi and Pinto (2016) consider communication skills to be among the advantages of RT, a finding which is also supported by the current study. The results can also be generalized for high achievers and low achievers in reading comprehension, as RT is effective with groups of different proficiency levels (Ahmadi \& Gilakjani, 2012).

The researcher suggests that sharing these findings with the students might generate motivation to participate to a greater extent in reading comprehension classes. Moreover, when the teacher becomes aware of students' perceptions, she will be encouraged to find ways to increase students' willingness to engage in such classes. In addition, structured interviews with the teacher and students may be carried out to obtain further data. Unfortunately, the survey did not evaluate students' achievement in reading comprehension, accordingly, the researcher suggests using the questionnaire in combination with other achievement measures.

The results could shed light on how to make the best use of RT in EFL classrooms. Moreover, the current study can pave the way for future research to thoroughly investigate the underlying cognitive mechanisms of reading comprehension and motivation and how they are linked to RT. Based on the results presented here, teachers can also decide on a comprehensive method for the teaching of reading and will research the problems posed by learners' lack of comprehension of reading texts and poor motivation to undertake reading. This research will thus contribute to TESOL innovation to improve levels of comprehension among EFL learners.

\section{Conclusion and recommendations}

The aim of this study is to examine whether implementing RT in English classes changes students' perception of their RT skills, reading comprehension and motivation to read. The study also hypothesizes the existence of correlations between RT and reading comprehension, and RT and motivation. The results show that RT is effective in improving students' perception of their reading skills and motivation. However, the current study is limited by the age, gender and first language of its respondents, and lacks the results of tests carried out on reading comprehension. It also lacks teachers' opinions on RT. Therefore, the researcher recommends research be continued into optimal methods to enhance students' reading skills and motivation to read. In particular, the following studies are proposed:

1) A comparative research across different school grades with the aim of applying pre-test and post-test scores to the effect of RT strategies on students' achievements, and to correlate these to students' attitudes towards RT.

2) A study that focuses on teachers' perceptions of the difficulties they face when implementing RT.

3) A study that implements a quasi-experimental design to test the effects of external motivations on teachers' readiness to apply RT strategies in reading classes.

Arab World English Journal 
4) A comparative study that compares the effects of RT with other teaching strategies, such as collaborative learning, to determine the most successful and applicable method for teaching reading in English to native Arabic learners.

Overall, the current findings are informative as concerns the importance of RT in teaching native Arabic speakers reading in English classes. Hence, the researchers recommend the following applications:

1) To offer training courses on RT strategies to English teachers. Training courses should cover the importance of using RT, implementation techniques and how to evaluate students' achievement and RT skills in reading.

2) To use successful experiences in using RT as models, and as benchmarks for other schools and educational centres.

3) To integrate the use of RT in EFL reading classes with the use of technology, which is becoming increasingly essential for $21^{\text {st }}$-century classes.

\section{About the Author:}

Maysa has an MA in TESOL form the English Language Institute in King Abdulaziz University, Jeddah, KSA. She has 24 years of experience in the field of education as she has worked as an English teacher for all grades and an English supervisor for high school at Albayan Model School, Jeddah. She is also the program coordinator for the gifted students and the academic accreditation coordinator for the diploma students at the same school. She is a certified internal audit from Mohammad Bin Rashid College, Dubai, AEU. She looks forward to working on more research that adds value to English teaching. ORCid ID: http://orcid.org/0000-0003-1716-2316

\section{References}

Ahmadi, M. R. \& Gilakjani, A. P. (2012). Reciprocal teaching strategies and their impacts on English reading comprehension. Theory and Practice in Language Studies, 2(10), 2053.

Ahmadi, M. R., Ismail, H. N., \& Abdullah, M. K. K. (2013). The Importance of Metacognitive Reading Strategy Awareness in Reading Comprehension. English Language Teaching, 6(10), 235-244.

Al-Harby, J. S. S. (2016). The Effect of Reciprocal-Teaching Strategy on Learning Outcomes and Attitudes of Qassim-University Students in "Islamic Culture". Journal of Education and Practice, 7(6), 213-231.

Ashegh, L. (2018). The Effects of Reciprocal Teaching on Reading Comprehension of Iranian EFL Learners. Advances in Language and Literary Studies, 9(4), 26-30. DOI:10.7575/aiac.alls.v.9n.4p.26

Bean, T. W., \& Steenwyk, F. L. (1984). The effect of three forms of summarization instruction on sixth graders' summary writing and comprehension. Journal of Literacy Research, 16(4), 297-306. DOI:10.1080/10862968409547523 
Doctorow, M., Wittrock, M. C., \& Marks, C. (1978). Generative processes in reading comprehension. Journal of Educational Psychology, 70(2), 109-118. DOI:10.1037/00220663.70.2.109.

Gomaa, O. M. K. (2015). The Effect of Reciprocal Teaching Intervention Strategy on Reading Comprehension Skills of 5th Grade Elementary School Students with Reading Disabilities. Online Submission, 4(2), 39-45.

Graesser, A., \& Lehman, B. (2011). Questions drive comprehension of text and multimedia. In M. T. McCrudden, J. P. Magliano, \& G. Schraw (Eds.), Text relevance and learning from text (pp. 53-74). Charlotte, NC: Information Age.

Gulbinskienè, D. \& Dubovičienè, T. (2015). Language Learning Motivation of EFL Students at LEU. Man \& the Word/Zmogus ir zodis, 17(3).

Head, M. H., Readence, J. E., \& Buss, R. R. (1989). An examination of summary writing as a measure of reading comprehension. Literacy Research and Instruction, 28(4), 1-11. DOI: $10.1080 / 19388078909557982$

Huang, C. T., \& Yang, S. C. (2015). Effects of online reciprocal teaching on reading strategies, comprehension, self-efficacy, and motivation. Journal of Educational Computing Research, 52(3), 381-407.

Ishiwa, K., Sanjose, V. \& Otero, J. (2013). Questioning and reading goals: Information-seeking questions asked on scientific texts read under different task conditions. Educational Psychology, 83(3), 502-520. DOI; 10.1111/j.2044-8279.2012.02076.

Ilter, B. G. (2009). Effect of technology on motivation in EFL classrooms. Turkish Online Journal of Distance Education, 10(4).

Krashen, S. (1989). We acquire vocabulary and spelling by reading: Additional evidence for the input hypothesis. The Modern Language Journal, 73(4), 440-464.

Liu, A. \& Bu, Y. (2016). Reciprocal Learning Strategy in CALL Environment: A Case Study of EFL Teaching at X University in Shanghai. Universal Journal of Educational Research, 4(5), 1059-1070.

Mandel, E., Osana, H. P., \& Venkatesh, V. (2013). Addressing the effects of reciprocal teaching on the receptive and expressive vocabulary of 1st-grade students. Journal of Research in Childhood Education, 27(4), 407-426.

McCrudden, M. T., Magliano, J. P., \& Schraw, G. (2010). Exploring how relevance instructions affect personal reading intentions, reading goals and text processing: A mixed-methods study. Contemporary Educational Psychology, 35(4), 229-241.

DOI:10.1016/j.cedpsych.2009.12.001.

Ninsuwan, P. (2015). The Effectiveness of Teaching English by Using Reading Aloud Technique towards EFL Beginners. Procedia-Social and Behavioral Sciences, 197, 1835-1840.

Palinscar, A. S. \& Brown, A. L. (1984). Reciprocal teaching of comprehension-fostering and comprehension-monitoring activities. Cognition and Instruction, 1(2), 117-175. 
Pilten, G. (2016). The Evaluation of Effectiveness of Reciprocal Teaching Strategies on Comprehension of Expository Texts. Journal of Education and Training Studies, 4(10), 232-247.

Ramsay, C. M., Sperling, S. A., \& Dornisch, M. M. (2010). A comparison of the effects of students' expository text comprehension strategies. Instruction Science, 38, 551-570. DOI: $10.1007 / \mathrm{s} 11251-008-9081-6$.

Reichenberg, M. \& Kent, L. Ã. (2014). An intervention study in grade 3 based upon reciprocal teaching. Journal of Education and Learning (EduLearn), 8(2), 122-131.

Rosenshine, B., Meister, C., \& Chapman, S. (1996). Teaching students to generate questions: A review of the intervention studies. Review of Educational Research, 66(2), 181-221. DOI:10.3102/00346543066002181.

Schünemann, N., Spörer, N., Völlinger, V. A., \& Brunstein, J. C. (2017). Peer feedback mediates the impact of self-regulation procedures on strategy use and reading comprehension in reciprocal teaching groups. Instructional Science, 45(4), 395-415.

Sheng-Shiang Tseng \& Hui-Chin Yeh (2018) Integrating reciprocal teaching in an online environment with an annotation feature to enhance low-achieving students' English reading comprehension, Interactive Learning Environments, 26(6), 789-802. DOI:10.1080/10494820.2017.1412989

Soonthornmanee, R. (2002). The effect of the reciprocal teaching approach on the reading comprehension of EFL students. RELC Journal, 33(2), 125-141.

Soufi, N., Saad, K., \& Nicolas, M. O. D. (2015). Blogs as a way to enhance EFL reading classes in a Lebanese tertiary institution. Teaching English with Technology, 15(1), 31-47.

Tarchi, C. \& Pinto, G. (2016). Reciprocal teaching: Analyzing interactive dynamics in the coconstruction of a text's meaning. The Journal of Educational Research, 109(5), 518-530.

Wang, Z., Sabatini, J., O’Reilly, O. \& Feng, F. (2017). How individual differences interact with task demands in text processing. Scientific Studies of Reading, 21(1) http://dx.DOI.org/10.1080/10888438.2016.1276184.

Zablocki, M., Horn, B. R., \& Cuenca-Carlino, Y. (2017) Effects of Reciprocal Teaching Strategies on the Reading Comprehension of Adolescents at an Alternative School. Illinois Reading Council Journal, 45(2), 11-21. 
Arab World English Journal (AWEJ) Volume 11. Number 1March 2020

The Influence of Implementing Reciprocal Teaching in L2 Classes

Qutob

Appendix A

A Self-report Questionnaire of Reading Abilities and Motivation

\begin{tabular}{|c|c|c|c|c|c|c|}
\hline & & 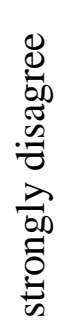 & 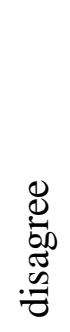 & 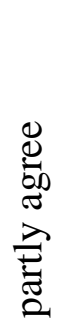 & 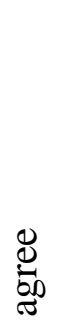 & 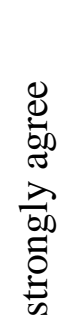 \\
\hline \multirow{4}{*}{ 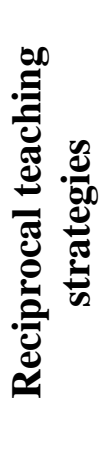 } & I can give precise predictions on the topic. & & & & & \\
\hline & I can clarify meanings of words through context. & & & & & \\
\hline & I can ask questions to expand my knowledge. & & & & & \\
\hline & $\begin{array}{l}\text { I find it easy to summarize the reading text to convey the } \\
\text { main ideas. }\end{array}$ & & & & & \\
\hline \multirow{4}{*}{ 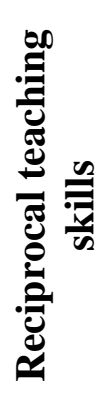 } & I can elicit specific information from a reading text. & & & & & \\
\hline & I can refer ideas of text to real-life experiences. & & & & & \\
\hline & I can find answers to the comprehension questions. & & & & & \\
\hline & $\begin{array}{l}\text { I can comprehend the main idea of a text by referring to the } \\
\text { title and the illustrations. }\end{array}$ & & & & & \\
\hline \multirow{5}{*}{ 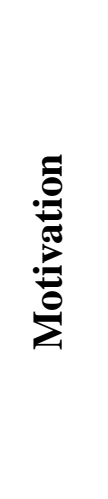 } & I tend to read more about difficult topics. & & & & & \\
\hline & $\begin{array}{l}\text { I enjoy discussing the reading comprehension with my } \\
\text { classmates. }\end{array}$ & & & & & \\
\hline & I am not embarrassed to read out loud in front of my class. & & & & & \\
\hline & If the topic is interesting in class, I tend to read more about it. & & & & & \\
\hline & I like the reading comprehension class. & & & & & \\
\hline
\end{tabular}

Arab World English Journal 